\title{
The Impact of TPB on Entrepreneurial Intentions
}

\author{
Fayeq Ali $\mathrm{Ali}^{1}$ \\ ${ }^{1}$ Department of Business Management, Faculty of Administrative Sciences, Tishk International University, Erbil, Iraq \\ Correspondence: Fayeq Ali Ali, TIU, Department of Business and Management, Erbil, Iraq. \\ Email: fayeq.ali@tiu.edu.iq \\ Doi: 10.23918/ejmss. v1i3p1
}

\begin{abstract}
The current research aims to undertake a study on the impact of the theory of planned behavior on the entrepreneurial intentions among undergraduate students of both business and accounting departments at Tishk International University, Erbil. Based on the theoretical background there are factors which shapes an individual to have entrepreneurial intentions such as personal and social factors (Bird,1988). The objective of this research is to evaluate which variable has more impact on the entrepreneurial intentions. The current research adopted quantitative method by distributing a questionnaire among undergraduate students. Data gathered through a Google form and used SPSS V. 25 for finding the impact of TPB on EI through both correlation and regression analysis. The finding shows that the Perceived Attitude has more impact on entrepreneurial intention comparing to subjective norms. This research concluded that Personal Attitude has more impact, after comes perceived Behavioral Control and a weak and less impact from subjective norm on entrepreneurial intentions.
\end{abstract}

Keywords: Entrepreneurial Intentions, Theory of Planned Behavior (TPB)

\section{Introduction}

Unprecedented economic crisis has created a huge unemployment among students in developed and especially in developing countries (Agolla et al., 2019). In order to improve this, policy makers in many countries and their governments' have encouraged their communities to find other employment alternatives as a source of income as entrepreneurs (Buli and Yesuf, 2015). The main point of being entrepreneur and entrepreneurship concept among students is because of its identification as a foundation of employment and income (Arrighetti et al., 2016). So, if the foundation and source of income can be improved among students by becoming entrepreneur, then this research is to investigate entrepreneurial intentions among business and management students in Tshik International University (TIU), Erbil, by employing the theory of planned behavior. As it is stated that the entrepreneurship can be seen as a source of employment and income among student and to lower unemployment so that this research is motivated to find out the intention before graduation. This research investigates whether business and management students of TIU got enough entrepreneurial skills to form a new venture or are willing to become entrepreneur or not. Apart from this gap, this research is centered to identify which variables of Theory of Planned Behavior impacts Entrepreneurial Intentions more than the other, so that students and educators, and society can concentrate on in boosting the youth entrepreneurial intentions among undergraduate students to start their own business.

\subsection{Research Questions}

Which variables of the TPB have more effect on Entrepreneurial Intentions?

\subsection{Research Objectives}

This research clearly aims to identify that which variables of TPB have more effect on entrepreneurial intention among undergraduate students of both Business and Accounting departments at Tishk International University.

\subsection{Hypotheses}

H1. Personal Attitude positively effects Entrepreneurial Intention (PA $\rightarrow$ EI)

H2. Subjective Norms positively effects Entrepreneurial Intention (SN $\rightarrow$ EI)

H3. Perceived Behavioral Control positively effects Entrepreneurial Intention (PBC $\rightarrow$ EI)

\section{Theoretical Background}

The term intention is defined by many researchers. According to Ajzen (2011) intention is as indications of a person's readiness to perform a behavior. Entrepreneurial intention is also viewed as someone's state of mind that guides and 
leads him/her about consideration, knowledge, activities, goals, commitments to perform in an entrepreneurial behavior (Fini, Grimaldi, Marzocchi, \& Sobrero, 2012). The fundamental argument that the entrepreneurial intention (EI) models is that entrepreneurship is an intentional and controlled behavior which is intrinsic rather than inborn, in which a person develops the EI over time and before acting to start a new venture (Bird, 1988; Krueger \& Carsrud, 1993). The intention movement to reach entrepreneurial behaviors may be moved by some factors, such as desires, ethics, needs, wants, lifestyles, beliefs and values (Lee \& Wong, 2004). The "choice intention" is also called as latent entrepreneurship which refers to people who wants to be independent as self-employed not working for other (Ajzen and Fishbein 1980; Verheul et al., 2012). The first stage of becoming entrepreneurship process as latent is important but not enough as a person desire is high to become entrepreneur (Atasoy, 2015), but it is not necessarily guaranteeing they will be one to pursue their own ideas. In the second phase, is about individual's commitment of the intention choice that he/she want to build a new business (Welsch, Liao, Pistrui, Oksöy, \& Huang, 2003). At the last phase is about entrepreneurial development of gathering enough skills and knowledge with the effort to establish that venture der (van der Zwan, Thurik, \& Grilo, 2010).

According to (TPB), entrepreneurial intentions (EI) indicate that people carry out that entrepreneurial behavior, which consists of three factors influences intention such as perceived attitude, subjective norms and perceived behavioral control (Ajzen, 1991). Perceived attitude/Personal attitude (PA) refers to the degree to which a person grasps a positive or negative behavior about being an entrepreneur (Kolvereid, 1996). It consists of being affective and also measurement of profit/advantages. Subjective norm (SN) refers to the noticed social pressure to like and dislike of becoming entrepreneur as referring to people approval and disapproval of a new business (Ajzen, 2001). Perceived behavioral control (PBC) has been described as the view of the simplicity or difficulty of fitting as becoming an entrepreneur (Shapero \& Sokol, 1982). PBC is not only the response of being entrepreneur, but the insight about control of the behavior, too.

Challenges to entrepreneurship may contain complications in gaining support from institution to become entrepreneurs, such as family support, financial support, supplier's relationship, and building market and finding customers. Getting support availability and access to experienced experts and institutional support as serviced for entrepreneurs has a constructive influence on EI. As a result, entrepreneurs look for such supports and if it is not provided then it became the main challenge for them as having intention to start a new venture (Luthje and Franke, 2003).

There are factors which shapes an individual to have entrepreneurial intentions such as personal and social factors (Bird,1988). This research would expect that the perceived attitude and social factors such as subjective norms have a positive relationship to EI, which the main concentration of the TPB is on three variables such as perceived attitude, subjective norms and perceived behavioral control, this research support the argument of Bird (1988) by testing the TPB as a base for entrepreneurial intentions among undergraduate students. Also, a study by Mirjana et al. (2018) found that the three variables of TPB positively affect the entrepreneurial intentions in Slovenia context.

\section{Research Methodology}

Research methodology is the use of the data by analyzing it based on the right method and techniques (Saunders, Lewis \& Thornhill, 2009). Right methods start from choosing the right research design, method of data collection and analyzing it by the right tools and program (Anol, 2012). In the current research positivism has been chosen because it relies on the data collection and interpretation of it. This research is purely quantitative with developed hypotheses deductively. Conducting research in social science discipline, survey is generally selected in exploratory and descriptive studies. According to Anol (2012) Survey is a good choice when the research is about analyzing people' opinion. A validated questionnaire is used to find out which variable of TPB effects the EI more than the other. The questionnaire is from (Linan \& Chen, 2009) for both TPB and EI, TPB with having three variables containing 14 items and EI with its 6 items. Adopted questionnaire got distributed through creating a Google Form and sharing on students Facebook webpage of Faculty of Administrative Sciences and Economics, Tishk International University, Erbil Branch. Students from both Business and Accounting Department were the target of this study and out of 288 students only 96 students filled the google form and for that researcher thanks their effort in participating in this research. There were 4 demographic questions such as gender, age, marital status, and field of study. And in the other part to find the effect of TPB on EI the are three dimensions within the TPB such as Perceived Attitude (PA) with 5 items, Subjective Norms (SN) having 3 items, Perceived Behavioral Control (PBC) including 6 items and the dependent variable as Entrepreneurial Intention (EI) with having 6 items. The questionnaire used was on a Likert scale from 1 to 7 . 


\section{EJMSS Eurasian Journal of Management \& Social Sciences}

Data Analysis

Table 1: Participants Profile

\begin{tabular}{cccc}
\hline Demographic Info & Items & Frequency & Percentage \\
\hline \multirow{2}{*}{ Gender } & Male & 34 & 35.4 \\
& Female & 62 & 64.6 \\
\hline \multirow{3}{*}{ Age } & $18-24$ & 42 & 43.8 \\
& $24-28$ & 35 & 36.5 \\
& $28-32$ & 12 & 12.5 \\
& $32-36$ & 6 & 6.3 \\
\multirow{2}{*}{ Marital status } & Above 36 & 1 & 1.0 \\
& Single & 73 & 76.0 \\
\multirow{2}{*}{ Field of Study } & Married & 23 & 24.0 \\
\hline & Business & 62 & 64.6 \\
& Accounting & 34 & 35.4 \\
\hline
\end{tabular}

Table (1) characterizes the percentages of participants' profile. The demographics are gender, age, marital status, and field of study. Participants are mainly female which is $64.6 \%$ and male are $35.4 \%$, this does not indicate that female are more than male in both departments rather shows that female participants have filled the questionnaire more than the male. The second demographic question asked about the participants age, in which, majority of them are among 18-24 years old and after comes 24-28, whereas only one student is above 36 old which indicates that all are youth and ready to tackle their journey of becoming entrepreneurs. Another question which was asked about participants' marital status, out of 96 students only 23 are married, whereas 73 are single, and the last question asked was about field of study, out of 96 students 62 were from Business and Management department and 34 were from Accounting department.

Table 2: Reliability Analysis

\begin{tabular}{llcc}
\hline$\#$ & Dimension & No. of Items & Cronbach's Alpha \\
\hline 1 & Perceived Attitude & 5 & .842 \\
2 & Perceived Behavioral Control & 6 & .839 \\
3 & Subjective Norms & 3 & .852 \\
4 & Entrepreneurial Intentions & 6 & .914 \\
\hline & & Overall Cronbach's Alpha (a) & .917
\end{tabular}

Table (2) indicates the Cronbach's Alpha of the computed variables in the TPB as independent variable and EI as dependent variable. Statistically Alpha of the current study of both TPB and EI is between (.839 to .914) which variables in Theory of Planned behavior and Items in Entrepreneurial Intentions are reliable from the greater to the smaller, Perceived Attitude with having 5 items Alpha level is .842, Perceived Behavioral Control consist of 6 items is .839, Subjective Norms with having 3 items Alpha level is .852, and Entrepreneurial Intentions alpha is .914, which indicates that internal consistency of all items in both independent and dependent variables are between excellent and very good. Cronbach's Alpha is a statistical technique to measure the internal consistency; which should have the same measure as all items in one variable measures the same internal consistency or not ? (Tavakol \& Dennick, 2011). According to George \& Mallery (2016) if Cronbach Alpha is greater than 0.9 is excellent, above 0.8 is very good, more than 0.7 is acceptable, below 0.6 is questionable, between 0.5 to 0.6 is weak and less than 0.5 is improper. 


\section{EJMSS Eurasian Journal of Management \& Social Sciences}

Table 3: Correlation Analysis

\begin{tabular}{|c|c|c|c|c|c|}
\hline \multicolumn{6}{|c|}{ Correlations } \\
\hline & & PA & SN & PBC & EI \\
\hline \multirow[t]{3}{*}{ PA } & Pearson Correlation & 1 & $.383^{* *}$ & $.476^{* *}$ & $.636^{* *}$ \\
\hline & Sig. (2-tailed) & & .000 & .000 & .000 \\
\hline & $\mathrm{N}$ & 96 & 96 & 96 & 96 \\
\hline \multirow[t]{3}{*}{$\mathrm{SN}$} & Pearson Correlation & $.383^{* *}$ & 1 & $.213^{*}$ & $.313^{* *}$ \\
\hline & Sig. (2-tailed) & .000 & & .038 & .002 \\
\hline & $\mathrm{N}$ & 96 & 96 & 96 & 96 \\
\hline \multirow[t]{3}{*}{$\mathrm{PBC}$} & Pearson Correlation & $.476^{* *}$ & $.213^{*}$ & 1 & $.587^{* *}$ \\
\hline & Sig. (2-tailed) & .000 & .038 & & .000 \\
\hline & $\mathrm{N}$ & 96 & 96 & 96 & 96 \\
\hline \multirow[t]{3}{*}{ EI } & Pearson Correlation & $.636^{* * *}$ & $.313^{* *}$ & $.587^{* * *}$ & 1 \\
\hline & Sig. (2-tailed) & .000 & .002 & .000 & \\
\hline & $\mathrm{N}$ & 96 & 96 & 96 & 96 \\
\hline
\end{tabular}

In Table (3) Pearson Correlation used to power the relationship between independent variable (TPB) and dependent variable (EI). The relationship between PA and EI is $\left(.636^{* *}\right.$, statistically significant of $\left..000, n=96\right)$ is positively correlated, means for each positive increase in PA, there is a positive increase in the EI and reverse is negative. The second is to measure the relationship between $\mathrm{SN}$ and EI, the Pearson Correlation is (.313** statistically significant of $.002, \mathrm{n}=96$ ) statistically significant but weaker relationship comparing to PA to EI. The last comparison which is PBC relationship with EI which is $\left(.587^{* *}\right.$ statistically significant of $\left..000, n=96\right)$ indicates a positive relationship closer to PA with EI.

Table 5: Regression Analysis

\section{Model Summary}

\begin{tabular}{lc|c|c|c} 
Model & $\mathrm{R}$ & R Square & $\begin{array}{c}\text { Adjusted } \mathrm{R} \\
\text { Square }\end{array}$ & Std. Error of the Estimate \\
\hline 1 & $.716^{\mathrm{a}}$ & .513 & .497 & 1.08084 \\
\hline
\end{tabular}

a. Predictors: (Constant), Perceived Behavioral Control, Subjective Norms, Perceived Attitude

The model summary confirmations of $(\mathrm{R})$ as the "multiple correlation coefficient". The "multiple correlation coefficient" (R) is the prediction quantity of independent variable (TPB) as $\left(.716^{\mathrm{a}}\right)$. (R) square percentage of the variance in the EI which is explained by the TPB, is $(.513)$ which mean that $(51.3 \%)$ of the independent variable (TPB) is explained by the dependent variable (EI). 


\section{EJMSS Eurasian Journal of Management \& Social Sciences}

\begin{tabular}{|c|c|c|c|c|c|c|}
\hline \multicolumn{7}{|c|}{ ANOVA $^{\mathrm{a}}$} \\
\hline Model & & Sum of Squares & df & Mean Square & $\mathrm{F}$ & Sig. \\
\hline \multirow[t]{3}{*}{1} & Regression & 113.301 & 3 & 37.767 & 32.329 & $.000^{\mathrm{b}}$ \\
\hline & Residual & 107.476 & 92 & 1.168 & & \\
\hline & Total & 220.777 & 95 & & & \\
\hline
\end{tabular}

a. Dependent Variable: Entrepreneurial Intentions

b. Predictors: (Constant), Perceived Behavioral Control, Subjective Norms, Perceived Attitude

Above table indications of the overall regression model is to know whether the model is a good fit for the data or not. Table show that independent variables (TPB) statistically significan which predicts the dependent variables (EI), model is a good fit as following, $\mathrm{F}(3,92)=32.329, \mathrm{P}$ of $\left..000^{\mathrm{b}}\right)$.

\section{Coefficients $^{\mathrm{a}}$}

\begin{tabular}{lll|c|c|c|c} 
& \multicolumn{2}{c|}{$\begin{array}{c}\text { Unstandardized } \\
\text { Coefficients }\end{array}$} & $\begin{array}{c}\text { Standardized } \\
\text { Coefficients }\end{array}$ & & \\
\hline \multirow{2}{*}{ Model } & & $\mathrm{B}$ & Std. Error & Beta & $\mathrm{t}$ & Sig. \\
\hline & & -.278 & .539 & & -.516 & .607 \\
\cline { 2 - 8 } & Perceived Attitude & .518 & .104 & .437 & 4.989 & .000 \\
\cline { 2 - 8 } & Subjective Norms & .068 & .078 & .069 & .871 & .386 \\
\cline { 2 - 8 } & Perceived Behavioral Control & .468 & .106 & .364 & 4.401 & .000 \\
\hline
\end{tabular}

a. Dependent Variable: Entrepreneurial Intentions

The Coefficients table shows that how much (EI) differs within (TPB). Perceived Attitude B value is .518 which means any increase in the Perceived Attitude, there is an increase in (EI) by (.518) equals to $51 \%$. The B value for Subjective Norms is (.068) and (.468) for Perceived Behavioral Control. In this study all independent variables such as Perceived Attitude and Perceived Behavioral Control impact EI but Subjective Norms influence is less comparing to other two variables of TPB.

\section{Findings and Conclusion}

The findings from the correlation analysis shows that there is a positive relationship between the variables of TPB and with Entrepreneurial Intentions (EI)as dependent variable. Research found out that the subjective norms have a weaker relationship with (EI) which this research objective is centered at finding which variable has more impact/effect with/on the (EI), SN with EI its Pearson Correlation is $\left(.313^{* *}\right.$ statistically significant of $\left..002, \mathrm{n}=96\right)$ in which PA to EI is $\left(.636^{* *}\right.$, statistically significant of $\left..000, n=96\right)$ means for each positive increase in PA, there is a positive increase in the EI. Research concludes that there is a positive relationship and impact with/on TPB on EI among undergraduate students of both accounting and business and management departments of Tishk International University (TIU). The R square shows that the variance in the EI which is explained by the TPB is (.513) which mean that $(51.3 \%)$ of the independent variable (TPB) is explained dependent variable (EI). This research is limited in its finding which only 53\% is explained by the TPB and the other percentage remains for other factors. This research expectation was that TPB have a positive relationship to EI, which the main concentration of the TPB is on three variables such as perceived attitude, subjective norms and perceived behavioral control, and this research supported the argument of Bird (1988) by testing the TPB as a base for entrepreneurial intentions among undergraduate students. Also, a study by Mirjana et al. (2018) found that the three variables of TPB positively affect the entrepreneurial intentions in Slovenia context. By this finding, this research confirms other findings by other researchers in other contexts as it is positive in Kurdistan context. 


\section{EJMSS Eurasian Journal of Management \& Social Sciences}

\section{Future Research Scope}

Further research is needed to develop a multidimensional hypothesis for entrepreneurial intentions such as tendency toward risk, patience to ambiguity, need for achievement, and comparing two different culture to understand the variances so that it could add more to the literature of both TPB and EI through applying the same method/one-sample $\mathrm{T}$ test to evaluate the influence of theory of panned behavior to the entrepreneurial intentions.

\section{References:}

Agolla, J., Monametsi, G., \& Phera, P. (2019). Antecedents of entrepreneurial intentions amongst business students in a tertiary institution. Asia Pacific Journal of Innovation snd Entrepreneurship, 13(2), 138-152. https://doi.org/10.1108/apjie-06-2018-0037

Ajzen, I. (1991). The theory of planned behavior. Organizational Behavior and Human Decision Processes, 50(2), 179-211.

Ajzen, I. (2001). Nature and operation of attitudes. Annual Review of Psychology, 52, $27-58$.

Ajzen, I. (2011). The theory of planned behavior: Reactions and reflections. Psychology \& Health, 26(9), 1113-1127. https://doi.org/10.1080/08870446.2011.613995.

Ajzen, I., \& Fishbein, M. (1980). Understanding attitudes and predicting social behavior. Englewood Cliffs: Prentice Hall.

Anol Bhattacherjee. (2012). Social Science Research: Principles, Methods, and Practices (2 ed.). Florida, USA: USF Tampa Library Open Access Collections.

Arrighetti, A., Caricati, L., Landini, F., \& Monacelli, N. (2016). Entrepreneurial intention in the time of crisis: a field study. International Journal of Entrepreneurial Behavior \& Research, 22(6), 835-859. https://doi.org/10.1108/ijebr12-2015-0326

Atasoy, H. (2015). Latent entrepreneurship in transition economies. IZA World of Labour, 155. https://doi.org/10.15185/izawol.155.

Bird, B. (1988). Implementing entrepreneurial ideas: The case for intention. Academy of Management Review, 13(3), $442-450$.

Buli, B., \& Yesuf, W. (2015). Determinants of entrepreneurial intentions. Education + Training, 57(8/9), 891-907. https://doi.org/10.1108/et-10-2014-0129

Fini, R., Grimaldi, R., Marzocchi, G. L., \& Sobrero, M. (2012). The determinants of corporate entrepreneurial intention within small and newly established firms. Entrepreneurship Theory and Practice, 36(2), 387-414. https://doi.org/10.1111/j.1540-6520.2010.00411.x.

George, D. and Mallery, P. (2016). IBM SPSS statistics 23 step by step. 14th ed. New York: Routledge, p. 231.

Kolvereid, L. (1996). Prediction of employment status choice intentions. Entrepreneurship Theory and Practice, 21(1), 47-57.

Krueger, N. F., \& Carsrud, A. (1993). Entrepreneurial intentions: Applying the theory of planned behavior. Entrepreneurship \&Regional Development, 5(4), 315-330. https://doi.org/10.1080/08985629300000020.

Lee, S.H. \& Wong, P.K. (2004). An exploratory study of technopreneurial intentions: A career anchor perspective. Journal of Business Venturing, 19(1), 7-28.

Linan, F., \& Chen, Y. (2009). Development and Cross-Cultural Application of a Specific Instrument to Measure Entrepreneurial Intentions. Entrepreneurship Theory and Practice, 33(3), 593-617. https://doi.org/10.1111/j.15406520.2009.00318.x

Luthje, C. \& Franke, N. (2003). The "making" of an entrepreneur: Testing a model of entrepreneurial intent among engineering students at MIT. Research and Development Management, 3(2), 135-147.

Mirjana, P., Ana, A., \& Marjana, M. (2018). Examining determinants of entrepreneurial intentions in Slovenia: applying the theory of planned behaviour and an innovative cognitive style. Economic Research-Ekonomska Istraživanja, 31(1), 1453-1471. https://doi.org/10.1080/1331677x.2018.1478321 


\section{EJMSS Eurasian Journal of Management \& Social Sciences}

Saunders, M., Lewis, P. and Thornhill, A. (2009). Research methods for business students. 5th ed. Harlow: Financial Times/Prentice Hall

Shapero, A. \& Sokol, L. (1982). Social dimensions of entrepreneurship. Encyclopedia of entrepreneurship (pp. $72-$ 80). Englewood Cliffs, NJ: Prentice Hall.

Tavakol, M. and Dennick, R. (2011). Making sense of Cronbach's alpha. International Journal of Medical Education, 2, 52-54.

van der Zwan, P., Thurik, A. R., \& Grilo, I. (2010). The entrepreneurial ladder and its determinants. Applied Economics, 42(17), 2183-2191. https://doi.org/10.1080/00036840701765437.

Verheul, I., Thurik, A. R., Grilo, I., \& van der Zwan, P. (2012). Explaining preferences and actual involvement in selfemployment: Gender and the entrepreneurial personality. Journal of Economic Psychology, 33(2), 325-341. https://doi.org/10.1016/j.joep. 2011.02.009.

Welsch, H., Liao, J., Pistrui, D., Oksöy, D., \& Huang, W. (2003). Entrepreneurial commitment, sacrifice, motivations and growth aspirations of Chinese entrepreneurs. Paper presented at the 17th Annual USASBE National Conference, South Carolina. 